Waldemar Mańkowski

wm.lodz@gmail.com

Badacz niezależny

\title{
Polityka gospodarcza jako działanie państwa na tle globalnych zmian
}

\section{Wstęp}

Na przełomie XX i XXI wieku ludzkość stanęła w obliczu globalnych zmian, przy których wszystkie dotychczas przeżyte rewolucje oraz sekularne fale niestabilności społeczno-politycznej mogą zmienić się w zaledwie nieznaczące incydenty. Poza zmianami świata społecznego, gospodarczego i politycznego podstawową determinantą biologicznego przetrwania ludzkości stają się, w pierwszych dekadach XXI wieku, transfiguracje geografii fizycznej Ziemi. Dynamika klimatu, topniejąca pokrywa lodowa, zanieczyszczenia lądów i oceanów oraz dynamiczne wymieranie gatunków to podstawowe efekty obecnej epoki, zwanej antropocenem.

W wymiarze politycznym zniknął ład światowy ukształtowany przez zimną wojnę. Dwubiegunowy porządek dobiegł końca na fali globalizacji, którą początkowo uznano za pożyteczny trend, a która obecnie wzbudza strach. Kryzysy finansowe obnażyły słabość kapitalizmu w jego neoliberalnej wersji. Dotychczasowe poglądy, że liberalna demokracja jest i pozostanie niezmiennym elementem ludzkiej kultury sprowokowała siły pozostające do niej w opozycji do przejmowania kontroli w miejscach, gdzie to możliwe. Powszechną bolączką społeczną są narastające gigantyczne nierówności. Kultura marketingu politycznego pozwala na stosunkowo łatwe manipulowanie masami ludzkimi. W wielu wypadkach wszystkie polityczne hamulce wymuszające zachowania zapewniające przestrzeganie dotychczasowych norm życia społecznego oraz polityki międzynarodowej przestają działać. Kreuje to polityczną i społeczną niestabilność, w konsekwencji stwarzając zagrożenia. Wśród zmian obalających stary porządek świata dynamicznie rozwijająca się gospodarka zarówno generuje zagrożenia, jak i stwarza nadzieje na przyszłość. 
W oczekiwaniu na nowy porządek państwo, jako najważniejsza organizacja społeczna, usiłuje nadawać kierunek zmianom. Celem artykułu jest przedstawienie polityki gospodarczej jako narzędzia interwencji państwa w ekonomiczną sferę życia społeczeństw. Wstępnym założeniem jest teza, że polityka ta ewoluuje wraz ze zmieniającym się otoczeniem gospodarki - jest więc obiektem permanentnego udoskonalania. Pytaniem badawczym jest zagadnienie, czy opisywane narzędzie - działanie państwa - jest na tyle mocne, żeby mogło być skuteczne. Przez taką skuteczność należy rozumieć, po pierwsze, możliwość realizacji założonych celów oraz, po drugie, możliwość takiego sformułowania celów, aby osiągnąć realny wpływ na życie gospodarcze i w konsekwencji także na inne sfery działania człowieka. Ostatecznym celem działania państwa w dziedzinie gospodarki winno być stwarzanie takich warunków, by ludzie byli w stanie dostosować się do zmieniającego się świata oraz byli w stanie osiągnąc i zachować dobrostan (istotna uwaga: wobec globalnej presji demograficznej, skorelowanej z coraz mniejszą dostępnością zasobów nie chodzi już o powszechny dobrobyt, lecz właśnie o dobrostan). Metodą analizy, jaką zastosowano w artykule, jest autorska analiza literatury przedmiotu. Ukierunkowano ją na ukazanie podstaw, jak również zmienności w czasie polityk gospodarczych państwa.

\section{Globalna zmiana - kreacja nowego świata}

Punktem wyjścia do rozważań o współczesnym świecie gospodarczym jest prawo ludności Thomasa Malthusa. Malthus, anglikański pastor i badacz problemów społecznych, opublikował w 1798 roku pracę An Essay on the Principle of Population. W pracy tej sformułował wniosek, że „klęska głodu [...] utrzymuje w równowadze liczbę ludności z liczbą żywności na świecie”. Stwierdził, że wzrost produkcji żywności zawsze doprowadzi do wzrostu liczby ludności. Pojawi się wtedy nowa siła robocza, a z czasem zarobki wskutek działania prawa podaży-popytu wrócą do poziomu biologicznego przetrwania. Stały wzrost poziomu życia jest więc niemożliwy. Postęp technologiczny czy niespodziewany dar natury - urodzaj lub brak niszczących klęsk, takich jak zarazy, może przynieść tylko wzrost demograficzny, a wzrost standardów życiowych, jeśli nastąpi, może być wyłącznie krótkotrwały². Sytuację taką określono jako pułapkę maltuzjańską. Pułapka ta towarzyszyła gospodarce społeczeństw od tysiącleci. Zgodnie z jej regułami działały zarówno słabo rozwinięte społeczeństwa peryferyjne, jak i cywilizacyjne centra, w tym na przykład rozwinięty ekonomicznie i organizacyjnie starożytny Rzym.

Reguły Malthusa przestały obowiązywać w jednym miejscu na Ziemi - w Anglii, prawdopodobnie około $1640 \mathrm{roku}^{3}$. Przezwyciężenie pułapki było procesem nieśpiesznym i długotrwałym. Wzrost dochodów ludności był początkowo powolny, ale systematyczny. Tempo wzrostu przyśpieszało od rewolucji przemysłowej w Anglii, poprzez rozwój

\footnotetext{
1 T.R. Malthus, Prawo ludności, Jirafa Roja, Warszawa 2007, s. 50.

2 Malthus pisał też o konieczności istnienia nierówności społecznych i o fatalnych jego zdaniem następstwach sytuacji, gdyby każdy miał pełne prawo do równej części produkcji ziemi. Tamże, s. 63, 64 .

${ }^{3}$ A. Leszczyński, Skok w nowoczesność. Polityka wzrostu w krajach peryferyjnych 1943-1980, Wydawnictwo Krytyki Politycznej, Warszawa 2013, s. 54.
} 
ekonomiczny wielkich obszarów, kryzysy polityczne (wojny światowe) i ekonomiczne (w tym największy kryzys kapitalizmu w latach 1929-1933). Zmiany były coraz szybsze - gospodarka rosła, następował rozwój społeczny i wzrost demograficzny. Rozszerzała się skala ingerencji w środowisko przyrodnicze. Przyroda, która wcześniej utrzymywała populację w stanie równowagi liczebnej, sama stała się przedmiotem działań i stopniowo uległa zmianom, które upoważniają do nazwania obecnej epoki geologicznej antropocenem $^{4}$. Końcowym efektem tych procesów stało się uformowanie dzisiejszego globalnego i dynamicznie zmieniającego się świata. W pierwszym dwudziestoleciu XXI wieku oczywiste stało się załamanie dotychczasowego porządku świata. Wizje przyszłości są, jak zawsze, obciążone wysokim stopniem niepewności. Niepewność ta jest immanentną cechą każdej prognozy. Jednak niepewność co do skutków obecnej zmiany jest dodatkowo wzmocniona tempem i nieprzewidywalnością skutków.

Początek obecnego etapu zmian można datować na moment zakończenia zimnej wojny. Skutki dotyczą wszystkich sfer życia. Pojawiła się wielobiegunowość, przede wszystkim polityczna, gospodarcza i militarna. Sieciowe społeczeństwo zaczęło funkcjonować zupełnie inaczej niż przed pojawieniem się internetu. Zmiany nastąpiły nie tylko w warstwie społecznej, wykreowały się również przekształcenia na poziomie osobniczym. Rodzące się pokolenia, otoczone siecią i sztuczną inteligencją, zmieniają sposób myślenia i postrzegania świata. Jak pisze badacz sieci: ,„pełen polotu umysł renesansu, racjonalny umysł oświecenia, nowatorski umysł rewolucji przemysłowej wkrótce może należeć do przeszłości"5. Zanika w świecie sieciowym zjawisko prywatności. Przepływy finansowe i informacyjne rozchodzą się z prędkością promieniowania elektromagnetycznego, co zmienia architekturę globalnej gospodarki. Pojawiają się w skali globalnej nowe bądź występujące dotychczas jako endemiczne choroby kreujące problemy społeczne. Dewastacja środowiska połączona ze wzrostem demograficznym oraz ze zmianami klimatycznymi tworzy zagrożenia. Skutki tych zjawisk są jeszcze dziś nierozpoznane. Nowe zjawiska pogodowe - według umiarkowanych prognoz - sprowadzą zasadnicze zmiany schematów pogodowych, które nie muszą przynieść końca świata ${ }^{6}$, jednak niewątpliwie oznaczać będą problemy dla miliardów ludzi. Tym samym podważą każdy aspekt dotychczasowej organizacji społeczeństwa ${ }^{7}$.

Suma zmian w niedalekiej już przyszłości przekonstruuje społeczeństwa, politykę i gospodarki. Zrodzi się nowy świat i wyłoni się inne społeczeństwo. Tak więc początek XXI wieku jest momentem powstawania nowego, oczekiwanego porządku. Charakteryzująca się turbulencjami i dynamicznymi, lawinowymi przełomami współczesność to czas interregnum.

${ }^{4}$ Takiego określenia użył Paul J. Crutzen - laureat Nagrody Nobla z dziedziny chemii w 1995 roku. E. Bińczyk, Epoka człowieka. Retoryka i marazm antropocenu, PWN, Warszawa 2018, s. 11.

5 N. Carr, Plytki umyst. Jak internet wptywa na nasz mózg, Wydawnictwo Helion, Gliwice 2013, s. 21.

${ }^{6}$ Inne, katastroficzne prognozy mówią, że w przypadku skrajnej bezradności rodzaju ludzkiego zmiany klimatu mogą doprowadzić do zniszczenia gatunku ludzkiego.

${ }^{7}$ M. Maslin, Zmiany klimatu, Wydawnictwo Uniwersytetu Łódzkiego, Łódź 2018, s. 11-13. 


\section{Życie gospodarcze na tle zmian z przełomu wieków}

Życie gospodarcze składa się z niepoliczalnych wektorów działań, podążających w różnych, często przeciwstawnych kierunkach - jego immanentną cechą są gry o sumie zerowej. Dodatkowo gry rynkowe charakteryzują się różną dynamiką w różnych obszarach. Przykładem służy, po pierwsze, rozwój technologiczny postępujący w tempie lawinowym, którego efekty są błyskawicznie wykorzystywane przez rynek. Po drugie, reakcje na dewastację środowiska przyrodniczego następują powoli i nie dotrzymują kroku szybkości dewastacji planety ${ }^{8}$. W takich okolicznościach państwo jako największy system społeczny ${ }^{9}$ próbuje regulować gospodarkę poprzez działania zwane polityką gospodarczą.

Poniżej zostanie przedstawiona polityka gospodarcza jako jedno z podstawowych zadań państwa. Polityka gospodarcza jest działaniem o ogólnospołecznym zasięgu, istotnie wpływającym na życie wszystkich członków społeczeństwa. Na tle ogólnego opisu zjawiska, który przedstawia źródła, podstawowe obszary i instytucje oraz ewolucję w reakcji na zachodzące zmiany, zobrazowany zostanie jeden z modeli polityki gospodarczej - europejski model społecznej gospodarki rynkowej. Należy przy tym zaznaczyć, że polityka gospodarcza jest w dużej części ripostą na zmiany, które już zaszły. Jej próby wyprzedzania wydarzeń są obarczone przywołanym wyżej zjawiskiem niepewności. Dlatego też odpowiedź polityki gospodarczej na zachodzące zjawiska może niekiedy wydawać się spóźniona.

\section{Polityka gospodarcza jako przykład polityki o ogólnospołecznym zasięgu}

Gospodarka jest strukturą o niezwykłym stopniu komplikacji, trudną tym samym do objaśnienia. Jak napisał już w połowie XX wieku Galbraith: „Pierwszym warunkiem zrozumienia współczesnego życia gospodarczego i społecznego jest jasny pogląd na zależność między wydarzeniami a pojęciami, które je thumaczą. [...] Gospodarka, tak jak inne przejawy życia społecznego, nie przystaje do prostego spoistego wzorca. Wręcz przeciwnie, często wydaje się bezładna, prymitywna i nielogiczna. Ale człowiekowi potrzebne jest wyjaśnienie"10.

\footnotetext{
8 Jest to związane z rabunkową eksploatacją środowiska, z której korzystają podmioty (gospodarcze, ale i polityczne) decydujące o całokształcie gospodarki. Przerzucają one w sposób bezwzględny tzw. koszty zewnętrzne (w tym wypadku koszty dewastacji środowiska) na ogół ludności. Ich partykularne interesy skłaniają do opóźniania i spowalniania reakcji na problemy związane ze środowiskiem przyrodniczym i brania odpowiedzialności za koszty zewnętrzne. W dominującej logice biznesu powszechne jest działanie w kategoriach gry, która toczy się o to, by wziąć jak najwięcej.

9 Państwo jest największym, w sensie jakościowym, systemem społecznym. Wprawdzie geograficzne wymiary lokują na czele organizacje ponadnarodowe, a zasoby kapitałowe i obroty największych korporacji są większe niż w gospodarkach niektórych państw, jednakże zasięg kompetencji państwo ma największy ze wszystkich systemów/organizacji społecznych.

10 J.K. Galbraith, Społeczeństwo dobrobytu. Państwo przemysłowe, PIW, Warszawa 1973, s. 25.
} 
W obliczu ogromnego stopnia komplikacji zjawisk gospodarczych nauki ekonomiczne dla objaśnienia dążeń i sposobu funkcjonowania społeczeństwa w sferze gospodarczej (a więc dla sprecyzowania celów polityki gospodarczej) - dopuszczają możliwość posługiwania się metaforami. Ułatwiają one zrozumienie skomplikowanych zjawisk w sytuacji, kiedy próby naukowego wyjaśnienia współczesnych procesów gospodarczych opisują świat pozornie nieobjaśnialny. Założeniem jest to, że biegłość w objaśnianiu i zrozumieniu procesów gospodarczych jest procesem intuicyjnym i wymagającym doświadczenia. Zgodnie z tą ideą metafory mają ułatwić rozumienie rzeczywistości. Tak więc sposoby wyjaśnienia fundamentalnych zjawisk ekonomicznych mogą przedstawić gospodarkę jako:

- mechanizm,

- system,

- dramat ${ }^{11}$.

Metafora mechanizmu nawiązuje wprost do systemu newtonowskiego, czyli opisu świata językiem matematyki. Matematyka i teoria gier są opisem praw życia społecznego, w tym gospodarczego. Metafora mechanizmu u podstaw sięga do teorii Leona Walrasa i jego analiz dotyczących mechanizmu równowagi jako pochodnej systemu cen, tak klarownego, że można je porównać do urządzenia (tzw. prawo Walrasa) ${ }^{12}$.

Metafora systemowa sięga do opisu systemów gospodarczych i do metodologii analiz systemowych. W tym ujęciu uznanie zdobyło podejście kontekstualne, wychodzące z założenia, że zjawiska, takie jak geografia, klimat, etniczność, język, kultura, ideologia, religia i technika wywierają wpływ na politykę, ale polityka nie wywiera na nie żadnego wpływu. Koncepcje takie zdominowały rozwój ekonomii neoklasycznej, a indywidualizm metodologiczny stanowił tu podstawę konstruowania teorii. Przedstawiciele kontekstualizmu uważają, że rezultaty systemowe są wynikiem interakcji między jednostkami działającymi spójnie z punktu widzenia zasad indywidualnego interesu.

W przeciwieństwie do poprzednich stanowisk, które eksponują determinizm w działaniach gospodarczych, metafora dramatu nawiązuje do chaosu i probabilizmu w działaniach człowieka (w ogólności, w tym działań gospodarczych). Nowe nurty ekonomii, w tym idee behawioralne, zaprzeczyły istnieniu homo oeconomicus. Jednocześnie wystąpiły niezauważane dotąd zjawiska, z których wyłania się obraz gospodarki jako dramatu. Zjawiska potęgujące zniewolenie, bezradność i zagubienie. Można tu przywołać przykład tzw. gospodarki kasyna (hegemonia finansów jako gry), narastających w skali dotychczas niewyobrażalnej nierówności oraz kosztów zewnętrznych działalności potęg ekonomicznych - niszczenie środowiska przyrodniczego czy generowanie zmian klimatu.

Powyższy krótki wstęp pozwala na zobrazowanie, jak skomplikowanym światem jest system gospodarczy i jak ważna, ale i złożona jest rola działań społecznych nazywanych polityką gospodarczą.

Polityka gospodarcza jest jedną z najważniejszych dziedzin polityki publicznej. Polega na programowaniu i prowadzeniu działań zmierzających do osiągnięcia dwóch celów, to

11 J. Wilkin, Instytucjonalne i kulturowe podstawy gospodarowania, Wydawnictwo Naukowe Scholar, Warszawa 2016, s. 38-52.

12 M. Blaug, Teoria ekonomii. Ujęcie retrospektywne, PWN, Warszawa 2000, s. 585. 
jest możliwie szybkiego tempa rozwoju gospodarczego oraz równowagi - stabilności makroekonomicznej w powiązaniu z osiąganiem innych społecznych celów rozwojowych ${ }^{13}$. Polityka gospodarcza i jej składowe klasyfikowane są z różnych punktów widzenia. Jako polityka podmiotowa dzieli się na rządową i komunalną (samorządową). Funkcjonalnie dzieli się na polityczno-gospodarcze podsystemy sektorowe, między innymi finansowy, budowlany, rolny i transportowy. Obszarowo obejmuje zasięg centralny i lokalny (regionalny) ${ }^{14}$.

Przedmiotem polityki gospodarczej jest gospodarka kraju, a więc przedsiębiorstwa prywatne i publiczne oraz gospodarstwa domowe, instytucje rynkowe i system prawa gospodarczego. Na osobne potraktowanie wśród przedsiębiorstw zasługują banki. Poświęca się im szczególną uwagę ze względu na hegemonię finansów ${ }^{15} \mathrm{~W}$ obrocie gospodarczym, wobec czego banki wymagają na przykład osobnego systemu nadzoru.

Podmiotem polityki gospodarczej są władze publiczne (rządowe i samorządowe), wyposażone w kompetencje decyzyjne przez władzę prawodawczą - parlament. Sferą działania jest natomiast głównie polityka makroekonomiczna, której elementami są polityka fiskalna i budżetowa, polityka pieniężna (w tym polityka kursowa) oraz polityka nadzoru ostrożnościowego nad sektorem finansowym (bankowym). Należy stwierdzić również, że rezultatem działań w skali makro jest wymuszanie określonych zachowań podmiotów mikroekonomicznych. Przytoczyć tu można reakcje przedsiębiorstw na rozwiązania z zakresu systemu podatkowego czy też działania podmiotów fizycznych w związku z polityką płacową. Na płaszczyznach podstawowych rozgrywają się wszystkie działania podsystemów gospodarczo-politycznych. Przykładem są polityki sektorowe.

\section{Niesprawności rynku jako źródło polityki gospodarczej}

W klasycznej pracy Adama Smitha Badania nad natura i przyczynami bogactwa narodów $^{16}$, czyli u samych podstaw współczesnej ekonomii jako nauki, jednoznacznie znajdują się odniesienia do rynku, konkurencji i alokacji zasobów jako bazy wzrostu i rozwoju gospodarczego. Smith zakłada, że efektywność gospodarcza osiągana jest przy braku zawodności rynku, to jest w warunkach konkurencji doskonałej (co jest rodzajem modelu idealnego). Indywidualne decyzje podmiotów gospodarujących, podejmowane we własnym interesie, prowadzą przy spełnieniu tego założenia do efektywności. Efektywność tę współcześnie określa się jako optimum w rozumieniu Pareta ${ }^{17}$. Główne nurty

13 D.K. Rosati, Polityka gospodarcza. Wybrane zagadnienia, Wydawnictwo SGH, Warszawa 2017, s. 15.

14 M. Żmigrodzki (red. nauk.), Encyklopedia politologii, t. 1., Kantor Wydawniczy Zakamycze, Kraków 1999, s. 233.

15 Chodzi tu o udział finansów w kreowaniu dochodów, który przewyższył już dochody produkowane przez sferę rzeczową. Istotny jest także sposób gospodarowania, który nie opiera się na tradycyjnych kalkulacjach, a jest wynikiem gier spekulacyjnych (co niekiedy określa się krugmanowskim terminem gospodarka kasyna).

${ }^{16}$ A. Smith, Badania nad natura i przyczynami bogactwa narodów, PWN, Warszawa 2007.

17 Vilfredo Pareto - ekonomista włoski, najsławniejszy przedstawiciel tzw. szkoły lozańskiej (matematycznej); opracował teorię wyborów; podkreślał, że ekonomia jest strukturalnie powiązana z socjologią i polityką gospodarczą. W. Stankiewicz, Historia myśli ekonomicznej, PWE, Warszawa 2000, s. 257-258. 
ekonomii akceptują kryterium optimum (efektywności) Pareta mówiące (w skrócie), że efektywne są takie rodzaje alokacji zasobów, po osiągnięciu których niczyjej sytuacji nie da się poprawić bez jednoczesnego pogorszenia sytuacji kogoś innego ${ }^{18}$. Innymi słowy, stan optimum to ten, który spotyka się z powszechną aprobatą, ponieważ nie kreuje zmian wywołujących konflikty. Ujęcie to było nowatorskie. Nowatorstwo polegało między innymi na tym, że Pareto zrezygnował z oceny zmian dobrobytu, jakie sprawiają, że jednym ludziom powodzi się lepiej, a wskutek tego innym powodzi się gorzej. Następstwem takiego podejścia była rezygnacja z koncepcji jakiegoś jedynego optimum społecznego i ustanowienie w zamian nieskończonej liczby nieporównywalnych optimów ${ }^{19}$.

Pareto był przedstawicielem tzw. ekonomii dobrobytu. Powstała ona na przełomie XIX i XX wieku i jako grupa koncepcji ustalających zasady optymalnego podziału wytworzonego produktu (z punktów widzenia ogólnospołecznego i indywidualnego), stała się początkiem polityki gospodarczej.

Neoliberalna myśl ekonomiczna, która osiągnęła sukces polityczny w końcu XX wieku, uznaje słusznie decydującą rolę rynku. Myślenie w kategoriach dominacji rynku i przy okazji jałowości prób sterowania grą rynkową scharakteryzował już w pierwszej połowie XIX wieku rosyjski pisarz Nikołaj Gogol. Jeden z jego bohaterów mówi: „Fabryki powstaną same z siebie, i powstaną właściwe fabryki, tego, co trzeba miejscowemu człowiekowi. A dalej, o teoretykach gospodarki - ekonomowie polityczni! Dureń na durniu siedzi i durniem pogania. Dalej swego głupiego nosa nie widzi! Osioł, a jeszcze na katedrę wlezie" ${ }^{20}$. W pierwszej połowie XXI wieku neoliberalne polityki gospodarcze prowadzone są przez liczne kraje. Jednym z przykładów jest Brazylia. Kraj ten, będący członkiem tzw. grupy BRICS ${ }^{21}$, typowany na wschodzącą potęgę przeżył kryzys gospodarczy i polityczny. Obecna polityka gospodarcza Brazylii (oparta w dużej części na rabunkowej eksploatacji zasobów przyrodniczych) nakierowana jest przede wszystkim na wzrost ilościowy i parametryczny, czyli na wzrost PKB. Narzędziami są między innymi prywatyzacja, stymulowanie inwestycji wewnętrznych i zagranicznych oraz wolnej konkurencji, a także „uniknięcie nadużywania władzy regulacyjnej przez państwo"22.

Współcześni zwolennicy liberalizmu gospodarczego często sięgają do argumentów prawnych, etycznych, socjologicznych i psychologicznych. Chwalą kreację poczucia odpowiedzialności wśród uczestników wolnej gry rynkowej. Zwracają uwagę na przykład na „optymistyczną wizję natury ludzkiej”23. Powołując się na słowa Friedricha von Hayeka,

18 J.E. Stiglitz, Ekonomia sektora publicznego, PWN, Warszawa 2004, s. 69.

19 M. Blaug, dz. cyt., s. 607.

20 N. Gogol, Martwe dusze, Znak, Kraków 2014, s. 397, 398.

${ }^{21}$ Brazylia, Indie, Chiny, Rosja i Południowa Afryka. Państwa te uznane zostały na początku wieku za wschodzące potęgi gospodarcze. Z czasem obraz ten uległ zmianie. Niektóre z krajów dotknęły kryzysy. Obecnie Brazylia przeprowadza program gospodarczy, który oficjalnie jest określany jako etap odbudowy podstaw gospodarki.

${ }^{22} \mathrm{Na}$ ten temat - H. da Rocha Vianna - ambasador Brazylii w Polsce, Przyspieszyć wzrost, ,Rzeczpospolita”, 14.11.2019.

${ }^{23}$ A. Kociołek-Pęksa, Polityka prawodawcza w obszarze gospodarki w kontekście zasad społecznej gospodarki rynkowej $i$ wolności gospodarczej. Uwagi z zakresu polityki prawa, [w:] J. Osiński, I. Zawiślińska (red.), Polityka publiczna. Teoria. Jakość. Dobre praktyki, Wydawnictwo SGH, Warszawa 2016, s. 71. 
eksponują moralną wartość decyzji podejmowanej w warunkach odpowiedzialności za własne działania. Wreszcie, odnosząc się do angażowania państwa w gospodarkę, uznają, że jest to usuwanie jednej niedoskonałości przez inną, ponieważ państwo jest co najmniej tak ułomne jak rynek ${ }^{24}$. W swojej, niekiedy skrajnej, apologetyce mechanizmów rynkowych nie chcą jednak zauważyć, że kreowanie przez rynek wyłącznie racjonalnych działań jest utopią. Idealny model smithowskiej konkurencji doskonałej istnieje jedynie w teorii. Chodzi tu nie tylko o racjonalność mikroekonomiczną (mit homo oeconomicus), ale też (a może przede wszystkim) o racjonalność w skali makro - w tym również społeczną. Teoretycy rozwoju społeczno-gospodarczego, od Karla Polany'ego i Emile'a Durkheima począwszy, uznali, że idea samodostosowującego się rynku jest utopią, a także, że nie istnieje kompletnie zatomizowane społeczeństwo ${ }^{25}$. Potwierdza to historia gospodarcza świata, która wskazuje, że dotąd nigdzie nie udało się wykreować racjonalnych zachowań zgodnych z ideą homo oeconomicus, nawet na poziomie mikroekonomicznym ${ }^{26}$. Do tego można dodać przytoczoną wcześniej myśl Galbraitha definiującą konkurencję jako grę o sumie zerowej. Fakty są więc uzasadnieniem konieczności wspomagania i korygowania mechanizmów rynku przez instytucje zewnętrzne, czyli państwo (lub w niektórych wypadkach przez instytucje ponadnarodowe) i jego politykę gospodarczą. Niedostatki faktycznie działającej konkurencji i mechanizmów rynkowych stały się przesłanką do poszukiwania alternatywnych mechanizmów alokacji zasobów i zaspokajania potrzeb. Te poszukiwania są zadaniem władzy publicznej. Polityka gospodarcza jest więc formą interwencji państwa w gospodarkę. Jej celem jest korygowanie działań rynku w taki sposób, by poprawić jego efektywność. Sama potrzeba prowadzenia polityki gospodarczej na ogół nie jest kwestionowana (mimo przytoczonych wątpliwości ortodoksyjnych neoliberałów). Spory teoretyczne i praktyczne dotyczą zakresu, celu i narzędzi interwencji oraz warunków realizacji ${ }^{27}$.

Historycznie obserwuje się cykliczne nasilanie (w okresie słabej koniunktury) oraz słabnięcie (w czasie dobrej koniunktury) aktywności państwa w gospodarce. Aktywności rozumianej jako interwencja w życie gospodarcze za pomocą uregulowań polityki ekonomicznej. Początki interwencjonizmu sięgają antyku ${ }^{28}$. Już Ateny, by chronić swój rynek wewnętrzny przed zalewem dóbr obcego pochodzenia, uciekły się do wprowadzenia ceł ochronnych. Można więc uznać, że interwencjonizm jest tak stary jak sama instytucja państwa. O ile aktywność państwa w gospodarce zaczynała się od ochrony wewnętrznego rynku, o tyle współcześnie zadania polityki gospodarczej dotyczą zupełnie innych zagadnień. Po okresie panowania neoliberalizmu (co było konsekwencją kryzysu zapoczątkowanego upadkiem w 2008 roku banku Lehman Brothers Holdings Inc.) rozpoczął się nawrót do idei głębszego zaangażowania państwa w działania gospodarcze. Neoliberalizm, który był przyczyną błędnych i niedostatecznych polityk makroekonomicznych,

24 Tamże, s. 66-70.

25 J. Hausner, Zarzadzanie publiczne, Wydawnictwo Naukowe Scholar, Warszawa 2008, s. 367.

26 R. Sobecki, Interwencjonizm, ale jaki?, „Kwartalnik Nauk o Przedsiębiorstwie” 2019, nr 2.

27 D. Rosati, dz. cyt., s. 19-21.

28 S. Kowalczyk, R. Sobiecki, Interwencjonizm w erze globalizacji, „Kwartalnik Nauk o Przedsiębiorstwie” 2019 , nr 2. 
sprowokował poważne deregulacje wielu niestabilnych dziedzin (w tym usług finansowych). Najważniejszymi obecnie problemami, które próbuje się rozwiązać za pomocą interwencjonizmu, są tzw. koszty zewnętrzne, które w ostatecznym rachunku prowadzą do degradacji środowiska przyrodniczego i społecznego oraz zmian klimatycznych. W sferze społecznej generują przede wszystkim głębokie nierówności dochodowe. Nierówności te mają poważne implikacje zarówno ekonomiczne, jak i społeczne.

Podstawę interwencji państwa w gospodarkę stanowi potrzeba zapewnienia trwałego wzrostu gospodarczego i rozwoju ekonomicznego przez mechanizmy rynkowe. W tej sytuacji państwo ma obowiązek gwarantować podstawy działania rynku (w tym stabilność prawa, stabilność polityczną i otwartość gospodarki). Jednocześnie immanentną cechą rynku jest jego zawodność zarówno jako stała cecha w niektórych obszarach, jak i występująca jednostkowo cecha w innych dziedzinach jako efekt błędów. Wkroczenie państwa w sferę gospodarki jest więc konieczne. Przejawami ułomności rynku są takie zjawiska, jak zawodność konkurencji (monopolizacja), niekorzystne efekty zewnętrzne, ogromna dysproporcja w podziale dochodów, niestabilność ekonomiczna objawiająca się cyklami koniunkturalnymi, pozacyklicznymi kryzysami oraz inflacją i bezrobociem. Poza tymi podstawowymi zjawiskami należy też zauważyć ograniczenia efektywności wynikające $\mathrm{z}$ niepełnej informacji, niekompletność rynku ${ }^{29}$, zawodność wynikającą z istnienia dóbr publicznych (koszt krańcowy ich produkcji = zero oraz brak możliwości wykluczenia kogokolwiek z udziału w korzystaniu z tych dóbr ${ }^{30}$ ). Należy ponadto odnotować, że wymienione przyczyny ułomności rynku są ze sobą powiązane, są współzależne, wzmacniają się nawzajem, działając na zasadzie sprzężeń zwrotnych.

Interwencja państwa $\mathrm{w}$ gospodarce również obarczona jest niedoskonałościami. Pierwszym ich przejawem może być przeregulowanie. Objawia się ono stwarzaniem niekorzystnych warunków dla gospodarowania przez poszczególne podmioty. Osłabia to konkurencję i w rezultacie może doprowadzić do załamania efektywności (optimum) Pareta. Przeregulowanie może być zarówno wynikiem błędów merytorycznych, jak i efektem dążenia do osiągnięcia doraźnych celów politycznych, co w dłuższym okresie może przełożyć się na osłabienie makroekonomicznej sytuacji kraju. Wzmacniaczem w tym przypadku staje się wszechwładna niemal perspektywa cyklów politycznych. Rodzi ona pokusę szkodliwego interwencjonizmu dla uzyskania partykularnych efektów politycznych, partyjnych czy wyborczych. Przykładem działań, kiedy odwołanie do zawodności rynku okazało się skutkiem ułomności interwencji państwa, może być opisana przez J. Stiglitza sprawa wprowadzenia cen minimalnych na produkty rolne ${ }^{31}$. Ceny w rolnictwie

${ }^{29}$ Polega ona na braku dostarczania przez rynek niektórych dóbr mimo ich kalkulacyjnej efektywności. Wymienia się tu jako przykłady rynki finansowe - ubezpieczenia, kredyty (J. Stiglitz, dz. cyt., s. 96). Można do tego zestawienia dodać rynek prywatnych usług medycznych w Polsce w latach 2018, 2019. Ze względu na masowe migracje klientów do prywatnych usługodawców obniża się jakość usług oraz zaczyna brakować możliwości ich realizowania (m.in. z powodu niedoboru personelu).

${ }^{30}$ Podaje się tu przykład latarni morskiej, która dla armatora statku jest darmowa, a więc nie można go zmusić do współfinansowania budowy. W rezultacie latarnia nie powstanie mimo rynkowej potrzeby jej istnienia (J. Stiglitz, dz. cyt., s. 95). Ostatnio zaczyna się na przykład brać pod uwagę możliwość współfinansowania przez pacjentów usług publicznej służby zdrowia, które dotychczas były bezpłatne.

31 J. Stiglitz, dz. cyt., s. 102. 
podlegają silnym wahaniom zarówno sezonowym, jak i długookresowym. Zwykle brak jest możliwości ubezpieczenia tego rodzaju ryzyk. Dodatkowo rynki są wysoce spekulacyjne. Jednak rolnicy interesują się wahaniami cen, o ile wpływają one na ich dochody. Stabilizowanie cen nie w pełni stabilizuje dochód, gdyż ten podlega wpływowi tak cen, jak i podaży towaru. Stabilizacja cen nie wpływa liniowo na wzrost dochodu, a niekiedy efekt może być odwrotny od założeń. W tej sytuacji zawodność rynku jest pretekstem do jego regulowania (przez wprowadzenie cen minimalnych), a nawet przeregulowania w celu osiągnięcia korzyści politycznych. Przykład Stiglitza można wzmocnić obrazkiem z Polski. Wobec obietnic stworzenia Narodowego Holdingu Spożywczego, który będzie kupował płody rolne po cenach „opłacalnych” (krótkookresowo) dla rolników, ekonomista Jerzy Wilkin stwierdza: „to jest gigantyczne złudzenie. [...] Rolnikom będzie lepiej, jak będą się mogli rozwijać. Tworzenie monopoli (holding) polega na niszczeniu konkurencji, a więc pogłębia niedoskonałość rynku"32. W tym przykładzie skupia się kilka omówionych wcześniej zagadnień. Należą do nich: monopolizacja jako element przeregulowania rynku (aż do stopnia możliwej przeciwskuteczności), potrzeba wolnej konkurencji oraz manipulacje w gospodarce jako narzędzie realizacji egoistycznych celów konkretnych polityków, a także krótkookresowa, związana z cyklem politycznym perspektywa.

\section{Społeczna gospodarka rynkowa i ordoliberalizm jako jego podstawa teoretyczna}

Konstytucja Rzeczypospolitej Polskiej w art. 20 stanowi, że: „Społeczna gospodarka rynkowa oparta na wolności działalności gospodarczej, własności prywatnej oraz solidarności, dialogu i współpracy partnerów społecznych stanowi podstawę ustroju gospodarczego Rzeczypospolitej Polskiej" ${ }^{33}$. Tak więc społeczna gospodarka rynkowa jest podstawą ustroju gospodarczego Rzeczypospolitej. Tym samym jest to podstawa polityki gospodarczej RP. Z konstytucyjnego zapisu wynika, że zawarte tam są zarówno warunki gospodarowania (gospodarka rynkowa), jak i realizacja celów społecznych (gospodarka społeczna).

Uznając społeczną gospodarkę rynkową (SGR) za podstawę działalności państwa w gospodarce, a także za ramy działalności podmiotów prywatnych, należy przyjrzeć się teoretycznym podstawom tego systemu gospodarczego.

Społeczna gospodarka rynkowa jest koncepcją z lat 30. (teorie ordoliberalne) i 40. (praktyka) XX wieku. Powstała w Republice Federalnej Niemiec. Wstępem była tu myśl Franza Oppenheimera, że „oparta na własności prywatnej wolność jednostek i rynkowa koordynacja ich działalności gospodarczej mogą być użyte do realizacji celów służących społeczeństwu jako całości"’34. Termin społeczna gospodarka rynkowa stworzył Alfred Müller-Armack, niemiecki ekonomista, który w zakres polityki gospodarczej włączył politykę społeczną jako integralną część. W jego ujęciu ten termin określał system go-

32 J. Solska, Władza za nieróbstwo, „Polityka. Niezbędnik Współczesny” 2019.

33 Dz.U. 1997, nr 78, poz. 483.

34 T. Kaczmarek, P. Pysz, Ludwig Erhard i społeczna gospodarka rynkowa, Instytut Studiów Politycznych PAN, Warszawa 2004, s. 9. 
spodarczy łączący własność prywatną z zasadą sprawiedliwości społecznej. Nazwano to trzecią drogą. Teza o współzależności ładu gospodarczego, politycznego i społecznego rządzących społeczeństwem stała się podstawą idei kolejnego niemieckiego ekonomisty, Waltera Euckena ${ }^{35}$. Opracował on koncepcję nowego ładu gospodarczego Niemiec po drugiej wojnie światowej. Eucken zaproponował wbudowanie rynku w określone ramy systemowe, które miały być narzucane przez państwo. Celem tych ograniczeń było zredukowanie możliwości działania (szczególnie w sferze rynkowej) grup interesu negatywnie wpływających na państwo i społeczeństwo. Opracował zbiór reguł, które określił mianem polityki ramowej. Podstawowym założeniem społecznej gospodarki rynkowej były państwowe gwarancje niezakłóconych procesów rynkowych przy odpowiedniej kontroli i regulacji gospodarki przez państwo. Taki program to ordoliberalizm, a jego początki sięgają lat 30. XX wieku. Był on próbą teoretycznej reakcji na gospodarkę ówczesnego kryzysu ekonomicznego cechującą się nieładem, chaosem i anarchią.

Z perspektywy ordoliberałów zarówno nauka Keynesa, jak i neoliberalne idee szkoły chicagowskiej ${ }^{36}$ mają - wprawdzie rzadko dostrzegane, ale tym niemniej istotne - podobne konsekwencje w razie ich zastosowania ${ }^{37}$. Te odmienne koncepcje polityki gospodarczej cechuje identyczne założenie w odniesieniu do pewnego aspektu tej polityki. Dotyczy ono bezpośredniego oddziaływania państwa na przebieg procesu gospodarowania. Keynesizm jest koncepcją dyskrecjonalnego sterowania przebiegiem procesu gospodarowania przez państwo od strony globalnego popytu poprzez zastosowanie instrumentów polityki fiskalnej i pieniężnej (stopa refinansowa banków komercyjnych). Neoliberalna koncepcja ekonomii podażowej i monetaryzmu proponuje oddziaływanie państwa ukierunkowane na rozmiary zagregowanej podaży oraz stabilność poziomu cen za pośrednictwem instrumentów polityki fiskalnej i podatkowej oraz friedmanowskiej reguły określającej przyrost ilości pieniądza w obiegu w zależności od wzrostu produktu krajowego brutto albo potencjału produkcyjnego gospodarki. Obie szkoły nie brały natomiast pod uwagę możliwości kształtowania (regulowania) ładu gospodarczego, to jest formalnych i nieformalnych reguł gry podmiotów rynkowych.

Najważniejsze różnice teoretyczne między tymi szkołami ekonomicznymi zostały zestawione w tabeli 1 .

35 E. Kundera (red.), Stownik historii myśli ekonomicznej, Wolters Kluwer business, Warszawa 2014, s. 66.

${ }^{36}$ Chicago School of Economics - szkoła ekonomii powstała w latach 30. XX wieku na Uniwersytecie w Chicago, głównymi przedstawicielami są Milton Friedman oraz George Stigler.

37 E. Mączyńska, P. Pysz, Liberalizm, neoliberalizm i ordoliberalizm, Referat na IX Kongres Ekonomistów Polskich, „Ekonomista” 2014, nr 2, http://195.187.97.25:8080/images/data/eko/wydania/No_2_2014/ PAN ekonomista_2014 2 1.pdf\#page $=65$ [dostęp: 27.02.2020]. 
Tabela 1. Ordoliberalizm, neoliberalizm i keynesizm - analiza porównawcza

\begin{tabular}{|c|c|c|c|c|}
\hline \multirow{2}{*}{$\begin{array}{c}\text { Koncepcje polityki } \\
\text { gospodarczej }\end{array}$} & \multirow{2}{*}{$\begin{array}{l}\text { Ład gospodarczy } \\
\text { Kształtowanie ładu }\end{array}$} & \multicolumn{3}{|c|}{ Przebieg procesu gospodarowania } \\
\hline & & $\begin{array}{c}\text { Wymiar } \\
\text { makroekonomiczny }\end{array}$ & $\begin{array}{c}\text { Wymiar } \\
\text { mikroekonomiczny }\end{array}$ & $\begin{array}{c}\text { Jednostki ludzkie } \\
\text { i ich emocje }\end{array}$ \\
\hline Ordoliberalizm & tak & tak & tak & tak \\
\hline Neoliberalizm & nie & tak & tak/nie & nie \\
\hline Keynesizm & nie & tak & nie & tak/nie \\
\hline
\end{tabular}

Źródło: E. Mączyńska, P. Pysz, Liberalizm, neoliberalizm i ordoliberalizm, Referat na IX Kongres Ekonomistów Polskich, „Ekonomista” 2014, nr 2, http://195.187.97.25:8080/images/data/eko/wydania/No_2 2014/PAN_ekonomista_2014_2_1.pdf\#page=65 [dostęp: 27.02.2020].

Analiza porównawcza wyraźnie wskazuje, że ordoliberalizm jako jedyna ze szkół rynkowych wskazuje na możliwość ingerencji państwa w ład gospodarczy. Neoliberalizm neguje wzajemny wpływ jednostek ludzkich i podmiotów w skali mikro na przebieg procesów gospodarczych. W takim ujęciu różnice między spierającymi się o podstawowe zasady szkołami - keynesizmem i neoliberalizmem wydają się niewielkie, ponieważ analiza ta nie uwzględnia skupienia ich uwagi na ekonomii popytowej (keynesizm) i podażowej (neoliberalizm). Tymczasem jest to właśnie aspekt zasadniczo dzielący te szkoły.

Głównym realizatorem praktycznego zastosowania założeń ordoliberalnych został Ludwig Erhard. Erhard i jego ekonomiści teoretycy odrzucili tezy Marksa o antagonistycznej sprzeczności między wolnością gospodarczą a równością i sprawiedliwością społeczną. Uznano, że społeczna gospodarka rynkowa jest syntezą wolności gospodarczej, odpowiedzialności podmiotów gospodarczych i równości społecznej ${ }^{38}$. Bazując na koncepcjach Müller-Armacka i Euckena, Erhard stworzył realnie działającą i przynoszącą szybkie efekty politykę gospodarczą.

Założeniami do wprowadzenia praktycznego było połączenie gospodarki rynkowej z zabezpieczeniem socjalnym. Polityka gospodarcza miała służyć realizacji celów o charakterze ogólnospołecznym oraz zagwarantować zabezpieczenia socjalne, tak by zmniejszyć ryzyko utraty środków do życia przez obywateli. Jako cele SGR widziano zapewnienie możliwie pełnego zatrudnienia, wspieranie regionalnej mobilności siły roboczej, czyli łagodzenie bezrobocia strukturalnego. Stawiano na odbudowę klasy średniej. Po okresie władzy NSDAP demokratyzowano oraz liberalizowano życie polityczne i gospodarcze. Założono ochronę pracy za pomocą regulacji stosunków pracy (regulacje stosunków pracodawca-pracownik) oraz działania na rzecz sprawiedliwego podziału dochodu narodowego przy jednoczesnej dbałości o wzrost wydajności w gospodarce. Był to program realizacji założeń teoretycznych ordoliberalizmu wskazujących na konieczność szerokiej regulacji - kształtowania ładu gospodarczego.

Porównanie nowego erhardowskiego systemu trzeciej drogi z innymi koncepcjami teoretycznymi przedstawia tabela 2 .

${ }^{38}$ T. Kaczmarek, P. Pysz, dz. cyt., s. 105, 111, 112. 
Tabela 2. Społeczna gospodarka rynkowa a kapitalizm typu laissez-faire i socjalizm typu marksistowskiego

\begin{tabular}{|l|l|l|l|}
\hline \multicolumn{1}{|c|}{ Kapitalizm laissez-faire } & \multicolumn{1}{|c|}{ Wolność jednostki } & Nierówność społeczna & $\begin{array}{l}\text { Państwo spełniające w gospo- } \\
\text { darce rolę „stróża nocnego” }\end{array}$ \\
\hline $\begin{array}{l}\text { socjalizm typu } \\
\text { marksistowskiego }\end{array}$ & $\begin{array}{l}\text { wolność jednostki } \\
\text { ograniczona do minimum }\end{array}$ & $\begin{array}{l}\text { równość i sprawiedliwośćc } \\
\text { społeczna* }\end{array}$ & $\begin{array}{l}\text { państwo zarówno kształtuje, } \\
\text { jak i reguluje proces } \\
\text { gospodarczy }\end{array}$ \\
\hline $\begin{array}{l}\text { społeczna gospodarka } \\
\text { rynkowa }\end{array}$ & wolność jednostki & $\begin{array}{l}\text { równość i sprawiedliwośćc } \\
\text { społeczna }\end{array}$ & $\begin{array}{l}\text { państwo ogranicza się } \\
\text { do kształtowania ładu } \\
\text { gospodarczego }\end{array}$ \\
\hline
\end{tabular}

${ }^{*} \mathrm{~W}$ tym wypadku jest to założenie czysto teoretyczne.

Źródło: T. Kaczmarek, P. Pysz, Ludwig Erhard i społeczna gospodarka rynkowa, Instytut Studiów Politycznych PAN, Warszawa 2004, s. 110.

Jak widać z powyższego zestawienia, społeczna gospodarka rynkowa stara się być integracją wybranych elementów z innych typów koncepcji ustrojowych. Fazy czasowe rozwoju polityki SGR oraz ich inspiracje teoretyczne pokazuje tabela 3.

Tabela 3. Fazy polityki społecznej gospodarki rynkowej w Niemczech

\begin{tabular}{|l|l|l|l|}
\hline Zadanie, inspiracje/czas & \multicolumn{1}{|c|}{$1948-1966$} & \multicolumn{1}{|c|}{$1967-1982$} & \multicolumn{1}{c|}{$1982-1998$ i od 1998 } \\
\hline Główne zadanie & $\begin{array}{l}\text { stabilizacja, a nie wzrost } \\
\text { gospodarczy }\end{array}$ & $\begin{array}{l}\text { wzrost gospodarczy po- } \\
\text { przez pobudzanie popytu }\end{array}$ & $\begin{array}{l}\text { wzrost gospodarczy po- } \\
\text { przez ekonomikę podaży }\end{array}$ \\
\hline Inspiratorzy & $\begin{array}{l}\text { Walter Eucken, Ludwig } \\
\text { Erhard, inni ordoliberałowie }\end{array}$ & $\begin{array}{l}\text { John Maynard Keynes, } \\
\text { Walter Eucken }\end{array}$ & $\begin{array}{l}\text { Margaret Thatcher, Ronald } \\
\text { Reagan, Milton Friedman }\end{array}$ \\
\hline
\end{tabular}

* Czołowy przedstawiciel chicagowskiej szkoły ekonomii.

Źródło: T. Kaczmarek, P. Pysz, Ludwig Erhard i spoteczna gospodarka rynkowa, Instytut Studiów Politycznych PAN, Warszawa 2004, s. 140.

Przedstawione zmiany w czasie wyraźnie wskazują na zmienność zarówno celów, jak i ekonomicznych inspiracji. Wskazują też na pełne i szybkie włączenie się gospodarki RFN w światowy system ekonomiczny. Celem pierwszego etapu była odbudowa - stabilizacja ekonomiki po wojennych zniszczeniach. W latach późniejszych Niemcy odniosły błyskawiczny i znaczący na arenie światowej sukces, którego fundamentem była SGR. Tym samym zajęły mocną pozycję w głównym nurcie gospodarczym świata. W przytoczonym zestawieniu wskazuje na to przede wszystkim inspiracja ze strony anglosaskich teoretyków i praktyków najpierw keynesizmu, a następnie neoliberalizmu ${ }^{39}$. Zwrot od lat

39 Zwrot ku inspiracjom neoliberalnym w drugiej połowie XX wieku miał też miejsce w innych niż zachodnioeuropejskie modelach polityki ekonomicznej. Nastąpił on w krajach tzw. rozwijających się (w dużej części postkolonialnych), gdzie programowano forsowny rozwój, związany z planowaniem i nacjonalizacją gospodarki. Elity ekonomiczne ,szybko i radykalnie odeszły od wiary w państwo i socjalizm. Uwierzyły w rynek, wolny handel międzynarodowy i swobodny przepływ kapitału. Zjawisko to rozpoczęło się od wyczerpywania w krajach zachodnich wiary w keynesowski model wzrostu”' (A. Leszczyński, dz. cyt., s. 457). Tę nową rynkową ,wiarę” amerykański badacz ekonomii rozwoju William Easterly uzasadnił: „Bogaci mają rynki, biedni mają biurokrację" (W. Easterly, Brzemię białego człowieka, PWN, Warszawa 2008, s. 139). 
80. XX wieku w stronę inspiracji rodem $\mathrm{z}$ teorii Friedmana, jaki dokonał się w niemieckiej gospodarce, mógłby wydać się zaskakujący. Potwierdza jednak pozycję Niemiec w systemie światowym. Ekonomiczny sukces powojennych Niemiec stał się bodźcem do uznania SGR za ustrój gospodarczy wielu krajów, w tym Polski.

\section{Podstawy teorii polityki gospodarczej: funkcje, cele, instrumenty}

Dyscypliną teoretyczną, formułującą podstawy (szeroko rozumiane cele oraz narzędzia) realizacji polityki gospodarczej jako części polityki państwa jest teoria normatywna polityki gospodarczej. Określając ogólne funkcje tej polityki, można wyróżnić trzy zasadnicze elementy zwane triadą ${ }^{40}$ musgraviańską ${ }^{41}$, takie jak:

1. Funkcja alokacyjna - ma za zadanie kształtowanie wielkości i struktury alokacji zasobów, tak aby usługi i dobra publiczne dostarczone zostały w pożądanej ilości i jakości, jednocześnie ma zostać spełnione kryterium efektywności ekonomicznej, czyli maksymalizacja wartości produktu przy danych zasobach. Kryterium to jest jednym z dwóch możliwych wariantów tzw. zasady racjonalnego gospodarowania. Drugą opcją byłoby osiągnięcie pożądanego/założonego stanu ilościowego i jakościowego produktu przy założeniu minimalizacji poziomu nakładów. Druga opcja może być również uwzględniona przy określaniu pożądanej alokacji zasobów na przykład w wypadku konieczności oszczędzania środków z jednoczesnym zachowaniem założonego poziomu konsumpcji. Obszar tej funkcji to sfera mikroekonomiczna.

2. Funkcja stabilizacyjna - ma zapewnić łagodzenie wahań cyklu koniunkturalnego oraz niwelować występujące niecykliczne szoki popytowe albo podażowe. Jest to funkcja sfery makroekonomicznej.

3. Funkcja redystrybucyjna - ma na celu doprowadzenie do pożądanego podziału dochodu poprzez korektę pierwotnego dochodu za pomocą regulacji podatkowych. Jest tu brany pod uwagę wymiar pozaekonomiczny - społeczny i kryterium sprawiedliwości.

O ile dwie pierwsze funkcje regulują życie gospodarcze, o tyle trzecia wkracza w domenę wyboru politycznego i polityki społecznej.

Cele polityki gospodarczej są wielorakie. Za najważniejsze uznaje się: pełne zatrudnienie, stabilizację cen, sprawiedliwy rozdział dochodów, zrównoważony wzrost gospodarczy, równowagę budżetu i bilansu płatniczego, konkurencyjność gospodarki. Bardziej szczegółowe cele mogą odnosić się do konkretnych sektorów (np. przemysłu czy energetyki). Ponieważ zwykle wszystkich pożądanych stanów nie da się realizować jednocześnie, istotna jest wymienność celów. Cele gospodarcze państwa publikowane są w oficjalnych dokumentach, zawierających konkretne zapisy zamierzeń rządu w obszarze polityki gospodarczej. Są ujmowane zarówno jakościowo, jak i ilościowo. Przykładem

${ }^{40}$ D. Rosati, Polityka gospodarcza. Wybrane zagadnienia, Wydawnictwo SGH, Warszawa 2017, s. 61.

41 Richard Musgrave - ekonomista amerykański niemieckiego pochodzenia. Jego najbardziej cytowaną praca jest The Theory of Public Finance (1959), opisana jako, ,pierwszy anglojęzyczny traktat w tej dziedzinie”Richard Musgrave, https://en.wikipedia.org/wiki/Richard_Musgrave_(economist) [dostęp: 27.02.2020]. 
zapisu jakościowego może być zapowiedź walki z bezrobociem. W tym wypadku uzupełnieniem deklaracji jakościowej jest konkretny wskaźnik ilościowy (na przykład wskazany odsetek liczby bezrobotnych lub dynamika stopy bezrobocia). Skonkretyzowane cele polityki gospodarczej przybierają postać zmiennych matematycznych o określonych wartościach lub bez ustalania tych wartości. Mogą też być przedstawiane jako wartości funkcji agregujących różne zmienne ${ }^{42}$. Prostym przykładem takiego modelu matematycznego jest funkcja użyteczności jako jedna z wielu możliwych metod wyznaczania celów. Określenie społecznej funkcji użyteczności ma postać:

$$
\mathrm{U}=f(x, y) \text {. }
$$

Wartość zależy tu od wielkości jednoczesnej konsumpcji jednego i drugiego dobra przy założeniu osiągnięcia maksimum funkcji przy danych ograniczeniach dotyczących możliwości produkcyjnych w ramach posiadanych technologii. Wartości $x^{*}$ oraz $y^{*}$, dla $U^{*}=$ max stają się wyznaczonymi celami produkcji. Na rysunku 1 przedstawia się to następująco:

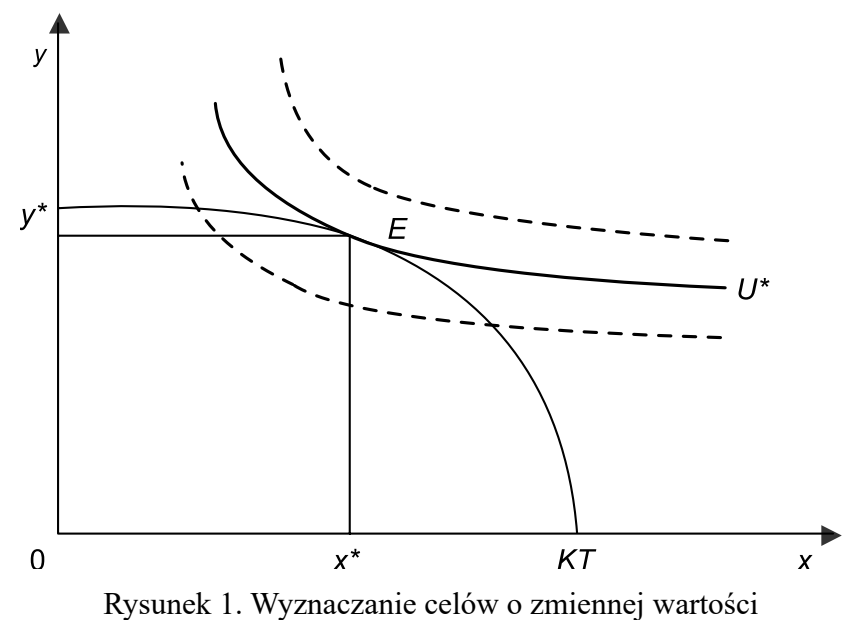

Źródło: D. Rosati, Polityka gospodarcza. Wybrane zagadnienia, Wydawnictwo SGH, Warszawa 2017, s. 67.

Na rysunku widnieje punkt styczności $E$ oraz wklęsła krzywa transformacji $K T$ i najdalej położona krzywa użyteczności $U^{*}$. Wyznaczają one pożądane i możliwe do osiągnięcia cele $x^{*}, y^{*}$. Krzywe $U$ poniżej $U^{*}$ są poziomem użyteczności niższym od $U^{*}$, krzywe $U$ leżące powyżej $U^{*}$ są poza obszarem możliwych rozwiązań.

Skwantyfikowane ilościowo (jak w powyższym przykładzie), czy też przedstawione jakościowo - opisowo, cele są podstawą do określania zmiennych ekonomicznych, technicznych i prawnych. Zmienne te stanowią instrumenty polityki gospodarczej, które rząd kontroluje i kształtuje w taki sposób, aby realizować założone cele. Ze względu na wielość możliwych instrumentów, które wpływają na kształtowanie zmiennych, rząd (przynajmniej na poziomie teoretycznym) dąży do wybrania najskuteczniejszych. Jedną z klasyfikacji instrumentów jest podział na politykę ilościową (zmiana wartości istniejących instrumen-

42 D. Rosati, dz. cyt., s. 66, 67. 
tów), jakościową (nowe instrumenty) i politykę reform (zmiany systemowe) ${ }^{43}$. Tradycyjny jest też podział na instrumenty bezpośredniej ingerencji (zakazy i nakazy, na przykład płace minimalne, limity ilościowe, regulacje cen) oraz na środki oddziaływania pośredniego (zmienne pobudzające podmioty rynkowe do określonych zachowań, na przykład regulacje podatkowe, subsydia). W praktyce stosowany jest też podział instrumentów na wyodrębnione obszary/skale oddziaływania. Są to instrumenty makroekonomiczne (na przykład polityka fiskalna - ustalanie poziomu wydatków i dochodów publicznych, i polityka pieniężna - kontrola i regulacja ilości pieniądza w obiegu) oraz mikroekonomiczne (w tym: podatki, subsydia, i inne regulacje dotyczące funkcjonowania określonych rynków, praw własności pomocy publicznej i regulacji dotyczących stosunków ekonomicznych między poszczególnymi uczestnikami gry rynkowej).

Ponieważ gospodarcza rzeczywistość jest nieskończenie złożona, narzędziem wiążącym cele $\mathrm{z}$ instrumentami polityki ekonomicznej stają się modele upraszczające obraz rzeczywistości. Pierwszym etapem jest tu budowa modelu ekonometrycznego. Opisuje on istniejące zależności między różnymi zmiennymi i przedstawia je w postaci funkcji matematycznej. Modele w postaci strukturalnej analizują zmiany wartości zmiennej objaśnianej (zależnej) od zmian zmiennych niezależnych, których liczba jest ograniczona). Często też pojawia się sytuacja, kiedy zmienne niezależne są jednocześnie także celami polityki. W konsekwencji buduje się tzw. modele zredukowane, gdzie zmiennymi niezależnymi są wyłącznie wielkości niebędące celami polityki. Przykładem takich przekształceń prostego modelu jest jeden z najbardziej popularnych makroekonomicznych modeli ekonometrycznych zwany IS-LM ${ }^{44}$. Część modelu ograniczona do równań równowagi rynku produktów (dla uproszczenia w warunkach gospodarki zamkniętej) przedstawia się w postaci strukturalnej następująco ${ }^{45}$ :

$$
\left.\begin{array}{l}
Y=C+I+G \\
C=a+c Y \\
I=b-g r
\end{array}\right\}
$$

Zmienne oznaczają: $Y$ - dochód, $C$ - konsumpcja, $I$ - inwestycje, $G$ - wydatki publiczne, $r$-stopa procentowa, $a, b, c$ - parametry modelu. Model ten za cele polityki uznaje poziom produkcji = dochodu, i poziom inwestycji. Instrumentami są: $G$-poziom wydatków rządowych i poziom stopy procentowej $-r$. W postaci strukturalnej zmienne pełnią podwójną rolę - objaśnianych i objaśniających. Zmienna celu $Y$ z pierwszego równania jest zmienną objaśniającą w drugim równaniu. Występują tu dwie zmienne celu, dwa instrumenty i aż trzy równania. Oznacza to, że układ można zredukować do dwóch równań. Po przekształceniach:

43 Jest to podział zaproponowany przez holenderskiego ekonomistę Jana Tinbergena.

${ }_{44}$ Model sformułowany przez Johna Hicksa w 1937 roku. Nazwa związana jest z podstawowymi zmiennymi modelu: $I$ - inwestycje, $S$ - oszczędności, $L$ - popyt na pieniądz, $M$ - podaż pieniądza. John Hicks - brytyjski ekonomista, laureat Nagrody Nobla w dziedzinie ekonomii w 1972 roku.

45 D. Rosati, dz. cyt., s. 70-72. 


$$
\left.\begin{array}{l}
Y=[(b-g r)+G+a] /(1-c) \\
I=b-g r
\end{array}\right\}
$$

W zredukowanej postaci cele polityki zależą wyłącznie od instrumentów $(G, r)$ i stałych parametrów $(a, b, c, g)$. Prosty przykład części modelu IS-LM pokazuje, że konstruowanie modeli polityki i warunków jej skuteczności wymaga użycia rozbudowanego warsztatu matematycznego.

Cele i instrumenty polityki powiązane są ze sobą regułami. Wśród istotnych reguł można wymienić przykładowo powiązanie stopy procentowej banku centralnego z dynamiką ilości pieniądza w obiegu oraz regułę uzależniającą wydatki budżetu od poziomu długu publicznego. Zasadność stosowania reguł obarczona jest obciążeniem w postaci trudności lub niemożności przewidzenia przyszłych warunków gospodarowania. Z drugiej strony ewentualna dyskrecjonalność może zwiększyć niepewność na rynku, a postępowanie według ogłoszonych publicznie reguł obniża prawdopodobieństwo podejmowania błędnych decyzji w grach rynkowych. Jan Tinbergen ${ }^{46}$ wykazał związek między liczbą celów a ilością instrumentów polityki. Warunkiem sukcesu polityki jest spełnienie kryterium, by liczba niezależnych instrumentów nie była mniejsza od ilości celów (dla $n$ instrumentów i $m$ celów wymóg skuteczności wskazuje żeby $n \geq m$ ).

Należy zauważyć podstawowe wady modelowania ekonometrycznego. Tak zwana krytyka Lucasa z 1976 roku zwraca uwagę na budzące wątpliwości założenia. W szczególności na nierealne założenie stabilności warunków gospodarowania w kolejnych okresach, na budowanie modeli na podstawie obserwacji z przeszłości oraz na brak uwzględniania sprzężenia zwrotnego między decyzjami politycznymi a decyzjami uczestników operacji rynkowych. Historycznie, zmatematyzowane modele ekonometryczne stały się jednym z kluczowych narzędzi prowadzenia interwencjonistycznej polityki gospodarczej od lat 40. aż po kryzys końca lat 70. XX wieku. Rozkwit rozpoczął się więc w czasach Johna Maynarda Keynesa - twórcy interwencjonizmu państwowego. Charakterystyczne, że sam Keynes podchodził do tych modeli sceptycznie ${ }^{47}$.

\section{Pomiar wyników polityki gospodarczej}

Istotnym zagadnieniem dotyczącym polityki ekonomicznej jest problem pomiaru efektów realizowanej polityki gospodarczej. W kompetencjach rządu lokuje się niewątpliwie formalne przeprowadzenie ewaluacji ex ante (etap projektowania działań), on-going (w trakcie realizacji). Te etapy ewaluacji mogą dotyczyć stanu realizacji poziomu zmiennych zaprogramowanych w polityce. Ewaluacja ex post może być również przeprowadzona jako raport z procesu osiągania poziomu założonych parametrów. Pomimo możliwości analizy parametrów nie da się jednoznacznie sporządzić raportu ex post, który mógłby

46 Jan Tinbergen - holenderski ekonomista i ekonometryk, pionier budowy modeli ekonometrycznych opisujących gospodarki narodowe.

47 D. Coyle, PKB. Krótka, lecz emocjonująca historia, PWN, Warszawa 2018, s. 21. 
zostać przeprowadzony za pomocą wystandaryzowanych metod badawczych i zobiektywizowanych kryteriów. Mnogość teorii ekonomicznych, w różny sposób oceniających pewne wielkości, nie pozwala na sformułowanie jednoznacznych wniosków. Także niepoliczalna jest ilość ocen polityki gospodarczej, które kreują na własny użytek wszyscy uczestnicy rynku. Są to zarówno podmioty wielkoskalowe, jak na przykład rząd i jego agendy, korporacje ponadnarodowe czy narodowe, instytucje finansowe, duże firmy, jak i podmioty działające w małej skali, czyli mikroprzedsiębiorcy, osoby fizyczne i gospodarstwa domowe. Występuje wyraźna nieciągłość skali racjonalności. Rozwiązania racjonalne z punktu widzenia wielkich graczy mogą być nieracjonalne dla indywidualnych podmiotów. Można też jako odrębny poziom wyróżnić racjonalność mezoekonomiczną odnoszącą się do skali regionu i średnich podmiotów.

Najbardziej używanym zarówno w profesjonalnych analizach, jak i w ocenach potocznych wskaźnikiem jest produkt krajowy brutto (PKB). Jest on miarą przepływu produktu w gospodarce w określonym czasie. Ocenia się jego poziom bieżący i dynamikę oraz kierunki zmian. Definicje pojęcia PKB są różne. W realnym świecie nie występuje byt zwany PKB. Jest to twór czysto statystyczny. Sposoby jego wyliczania pokazane są poniżej.

Tabela 4. Trzy sposoby wyliczania PKB

\begin{tabular}{l} 
I. Metoda wartości dodanej (produkcyjna) \\
Produkcja globalna brutto (sprzedaż brutto minus zmiana w stanie zapasów) \\
Minus zużycie pośrednie \\
Wynik: wartość dodana ze wszystkich branż \\
\hline II. Metoda dochodowa (według typów) \\
Suma: $\quad$\begin{tabular}{l} 
wypłat \\
dochodów z wynajmu \\
zysków i dochodów przedsiębiorców \\
podatków od produkcji i importu \\
Minus: subsydia \\
odsetek różnych \\
płatności \\
amortyzacji \\
Wynik: całość dochodu krajowego \\
\hline III. Metoda wydatkowa \\
kuma: \\
konsumpcji gotowych dóbr i usług przez gospodarstwa domowe \\
inwestycji w zakłady, wyposażenie, oprogramowanie \\
wydatków rządowych na dobra i usługi \\
bilans eksportu dóbr i usług (eksport minus import)
\end{tabular} \\
\hline
\end{tabular}

Źródło: D. Coyle, PKB. Krótka, lecz emocjonująca historia, PWN, Warszawa 2018, s. 25.

Statystycznie i księgowo powyższe trzy sposoby są ekwiwalentne. Sumują całość produkcji gospodarki oraz całość jej przychodów albo wydatków. Jest to statystyka brutto nieuwzględniająca amortyzacji zasobów (utraty wartości w czasie). Miernik PKB 
(wcześniej zwany PNB) stworzono do pomiaru działalności gospodarczej, włączając w nią sektor publiczny (ale nie gospodarstwa domowe). Nastąpiło to w związku z rozwojem gospodarek keynesowskich, gdy zmagano się ze skutkami wielkiego kryzysu, a rządy przejęły odpowiedzialność za zarządzanie gospodarką ${ }^{48}$. Wskaźnikiem pochodnym od PKB jest dochód narodowy, zwany też produktem krajowym netto (PKN). Z definicji mierzy on całość dochodów, jakimi rozporządzają mieszkańcy danego kraju w ciągu roku (i to niezależnie od formy prawnej). O ile PKB mierzy całość dóbr i usług wytworzonych w ciągu roku, to PKN pomniejsza się o amortyzację (zużycie kapitału) i powiększa o dochody netto uzyskane za granicą (albo pomniejsza, jeśli wystąpiły dochody netto płacone za granicą). Formuła wygląda następująco: dochód narodowy = produkcja krajowa + dochody netto pochodzace $z$ zagranicy ${ }^{49}$. Należy zauważyć, że PKB jest miarą wzrostu, a nie rozwoju. Mierzy zmiany ilościowe, parametryczne, podczas gdy w okresie obecnych, dynamicznych zmian istotny staje się wzrost. Jest on definiowany jako zmiana jakościowa - systemowa ${ }^{50}$. Zmiana jakościowa gospodarki i przeobrażenia społeczne zanurzone w otoczeniu fizycznym - geograficznym.

PKB jest w tej sytuacji miarą powszechnie znaną i obecnie powszechnie krytykowaną. Można powiedzieć, że „ostatnio [właśnie w obecnym czasie interregnum - WM] pękł z hukiem i trzaskiem balonik mającego ponoć trwać nieprzerwanie i w nieskończoność «wzrostu gospodarczego» mierzonego przyrostem PKB" ${ }^{51}$. Poziom i wzrost PKB jest w stanie współzależności ze zwiększeniem dobrostanu społeczeństwa. Nie każda jednak polityka dążąca do wzrostu PKB wpływa pozytywnie na zadowolenie społeczne. Forsowanie rozwoju mierzonego poziomem i dynamiką produktu robi się coraz bardziej wątpliwe w sytuacji ograbiania planety z zasobów naturalnych i dewastowania środowiska przyrodniczego. To, co się mierzy (tu PKB), nie powinno stawać się celem ${ }^{52}$. Zaznacza się więc tendencja do realokacji wagi mierzonych zjawisk. Znaczenia nabiera ekonomia zrównoważonego rozwoju, która mierzy efekty w kontekście ich wpływu na środowisko przyrodnicze, wprowadzając do kalkulacji nowe zmienne - stan środowiska i zasobów naturalnych, traktowany jako kapitał przyrodniczy. Problemem ludzkości stała się gospodarka nadkonsumpcji i nadprodukcji. W 2008 roku pojawił się ruch Research and Degrowth $^{53}$. Patronem intelektualnym ruchu jest ekonomista Nicolas Georgescu-Roegen ${ }^{54}$, który opublikował manifest The Entropy Law and the Economic Process (Prawo entropii a proces ekonomiczny). Jego stanowisko, w największym skrócie, mówi, że procesu entropii nie da się odwrócić, ale należy go spowolnić. W konsekwencji miary sukcesu należy odnosić do biofizycznego stanu ludzi - zapewnić maksymalnie możliwy poziom

48 J. Stiglitz, A. Sen, J.P. Fitoussi, Błąd pomiaru. Dlaczego PKB nie wystarcza, Polskie Towarzystwo Ekonomiczne, Warszawa 2013, s. XXXIII.

49 T. Piketty, Kapital w XXI wieku, Wydawnictwo Krytyki Politycznej, Warszawa 2015, s. 62.

50 J. Hausner, Zarzadzanie publiczne, Wydawnictwo Naukowe Scholar, Warszawa 2008, s. 370.

${ }^{51}$ A. Leszczyński, Skok $w$ nowoczesność. Polityka wzrostu w krajach peryferyjnych 1943-1980, Wydawnictwo Krytyki Politycznej, Warszawa 2013, s. 10.

${ }^{52}$ M. Piątkowski, Europejski lider wzrostu, Poltext, Warszawa 2019, s. 368.

53 Nazwa degrowth może być tłumaczona na polski jako od-wzrost lub wycof.

54 A. Leszczyński, Eksperymenty na biednych, Wydawnictwo Krytyki Politycznej, Warszawa 2016, s. $195,196$. 
zadowolenia z życia przy minimalnym zużyciu zasobów. Stanowisko takie jest wręcz sprzeczne z ekonomią neoklasyczną, która nie potrafi wycenić na przykład wolnego czasu, uważając go za koszt zmniejszający wydajność i produkcję. Jest też sprzeczne z ogólnie przyjętą zasadą racjonalnego gospodarowania. Zasada ta mówi albo o minimum nakładów przy osiąganiu założonego efektu, albo o maksymalizacji efektu przy założonych nakładach. Tymczasem Georgescu-Roegen ustala miarę dążącą jednocześnie do osiągania minimów i maksimów funkcji.

Istnieją więc związane z coraz aktualniejszymi problemami zmiany społecznej, inne niż PKB narzędzia pomiaru efektów polityki gospodarczej państwa i oceny jej wpływu na dobrostan społeczeństwa. Można je klasyfikować z uwagi na dziedzinę życia gospodarczego, którą mierzą (w tym między innymi produkcja, bezrobocie, inwestycje - analizowane pod kątem wolumenu, dynamiki, kierunków zmian, wydajność pracy, wskaźnik ze sfery finansów). Wskaźniki ekonomiczne mogą być oceniane i konstruowane z punktu widzenia różnych nurtów myśli ekonomicznej. Inaczej ocenią efekty i plany polityki gospodarczej ortodoksyjni wolnorynkowcy, a inaczej zwolennicy transferów socjalnych. W ocenie polityki ekonomicznej coraz ważniejsze są wskaźniki ściśle powiązane ze sferą społeczną. Pozostaje to w korelacji z pozaekonomicznymi politykami społecznymi oraz w ścisłym powiązaniu z rosnącą wagą problemu nierówności społecznych. Zauważono, że „długotrwała tendencja rozwojowa społecznych nierówności ulegać zaczyna odwróceniu [...] rozstęp standardów życiowych między krajami «rozwiniętymi» a «zacofanymi» czy «rozwijającymi się gospodarczo» kurczy się, gdy nierówności społeczne wewnątrz krajów «rozwiniętych» rosną znowu jak za dawnych i, zdawałoby się, na zawsze minionych lat, a przytem rosną w nigdy przedtem nienotowanym tempie i jak dotąd niepohamowanie" 55 . Wśród wskaźników mierzących aspekty społeczne polityki gospodarczej wymienić można:

1. Wskaźnik Giniego służący do liczbowego wyrażania nierównomiernego rozkładu dóbr, zwłaszcza dochodu (na przykład gospodarstw domowych). Problemem globalnym staje się narastający wzrost nierówności społecznych, zasygnalizowany na przykład przez Thomasa Piketty'ego ${ }^{56}$. Jest to nierówność fundamentalna, wyrażona związkiem liczbowym: $r>g$, gdzie $r$ jest wskaźnikiem rentowności kapitału, a $g$ oznacza przyrost produkcji i dochodu (stopa wzrostu). Kiedy rentowność (stopa zwrotu) kapitału znacząco przerasta stopę wzrostu (a jest to stała tendencja w XXI wieku), przychody z kapitału rosną szybciej niż gospodarka jako całość. Na skutek prawa skumulowanego wzrostu w długim terminie kreuje to nadzwyczaj silne efekty destabilizujące strukturę nierówności społecznych. Nasuwa się wniosek, że istnieje pilna potrzeba stworzenia polityk publicznych, mieszczących się w dziedzinie polityki gospodarczej, pozwalających przeciwdziałać skutkom tego zjawiska. Potrzebna jest korekta - wyższe podatki, większa redystrybucja dóbr. „Systemy demokratyczne z gospodarką rynkową radziły sobie najlepiej, gdy elity z wielkimi pieniędzmi miały poczucie społecznej odpowiedzialności’’57.

55 A. Leszczyński, dz. cyt., s. 11.

56 T. Piketty, dz. cyt., s. 41-43, 101.

57 R. Nowicki, Wywiad z Fukuyama. Liberalizm nie jest przeżytkiem, „Newsweek Polska” 2019, nr 42. 
2. Niedawno stworzony indeks lepszego życia $\mathrm{OECD}^{58}$, klasyfikujący kraje z holistycznego punktu widzenia ogólnej satysfakcji obywateli. Przypisuje on wagi takim tematom, jak dochody, służba zdrowia, bezpieczeństwo, mieszkanie. Uwzględnia oczywiście coraz bardziej istotny aspekt, jakim jest poziom dewastacji środowiska.

3. Pomiar relacji dochodów gospodarstw domowych do ich sztywnych wydatków (jeden ze wskaźników społecznych). Ten konkretny pomiar koresponduje z empirycznym prawem Engla mówiącym (w skrócie), że w miarę wzrostu dochodów maleją względne wydatki na żywność.

Problemy ubóstwa i nierówności społecznych (w konsekwencji i ekonomicznych) stały się na tyle istotne, że w 2019 roku nagrodę Szwedzkiego Banku Narodowego w dziedzinie nauk ekonomicznych otrzymało trzech ekonomistów: Abhijit Banerjee, Esther Duflo i Michael Kremer, „za eksperymentalne podejście do łagodzenia światowego ubóstwa”. Ciekawy, kilkunastominutowy wykład o swoich badaniach ubóstwa wygłosiła Duflo i, co charakterystyczne, został on umieszczony na popularnym i powszechnie oglądanym kanale internetowym YouTube. Zdaje się to świadczyć o rosnącym coraz bardziej zainteresowaniu problematyką ${ }^{59}$.

Ciekawą uwagę, niejako podsumowującą powyższe rozważania na temat polityki gospodarczej, przedstawił prezydent Francji Nicolas Sarkozy: „Jeśli nie przypiszemy żadnej wartości księgowej jakości służb publicznych, jeśli ograniczymy się do indeksu postępu ekonomicznego, który zawiera tylko to, co jest tworzone, a nie to, co jest niszczone, oraz jeśli skoncentrujemy się tylko na produkcie krajowym brutto [...] jak możemy oczekiwać, że zrozumiemy, co właściwie robimy i jak zmierzymy się z konsekwencjami? Rodzaj cywilizacji, jaką budujemy, zależy od sposobu, w jaki księgujemy, a to dlatego, że zmienia się wartość, jaką przypisujemy rzeczom"60.

\section{Bibliografia}

Bińczyk E., Epoka człowieka. Retoryka i marazm antropocenu, PWN, Warszawa 2018.

Blaug M., Teoria ekonomii. Ujęcie retrospektywne, PWN, Warszawa 2000.

Carr N., Ptytki umyst. Jak internet wpływa na nasz mózg, Wydawnictwo Helion, Gliwice 2013.

Coyle D., PKB. Krótka, lecz emocjonująca historia, PWN, Warszawa 2018.

da Rocha Vianna H., Przyspieszyć wzrost, ,Rzeczpospolita”, 14.11.2019.

Duczkowski N., Stwórz sobie lepsze życie, https://prnews.pl/stworz-sobie-lepsze-zycie-18883 [dostęp: 11.10.2019].

Easterly W., Brzemię białego człowieka, PWN, Warszawa 2008.

\footnotetext{
${ }^{58}$ N. Duczkowski, Stwórz sobie lepsze życie, https://prnews.pl/stworz-sobie-lepsze-zycie-18883 [dostęp: 11.10.2019].

${ }^{59}$ Esther Duflo: Social experiments to fight poverty, https://www.youtube.com/watch?v=0zvrGiPkVcs [dostęp: 18.11.2019].

${ }^{60}$ N. Sarkozy, Stowo wstępne, [w:] J. Stiglitz, A. Sen, J.P. Fitoussi, Btad pomiaru. Dlaczego PKB nie wystarcza, Polskie Towarzystwo Ekonomiczne, Warszawa 2013, s. XXI, XXXIII.
} 
Esther Duflo: Social experiments to fight poverty, https:/www.youtube.com/watch?v=0zvrGiPkVcs [dostęp: 18.11.2019].

Galbraith J.K., Społeczeństwo dobrobytu. Państwo przemysłowe, PIW, Warszawa 1973.

Gogol N., Martwe dusze, Znak, Kraków 2014.

Hausner J., Zarzadzanie publiczne, Wydawnictwo Naukowe Scholar, Warszawa 2008.

Kaczmarek T., Pysz P., Ludwig Erhard i społeczna gospodarka rynkowa, Instytut Studiów Politycznych PAN, Warszawa 2004.

Konstytucja Rzeczypospolitej Polskiej z dnia 2 kwietnia 1997 r., Dz.U. 1997, nr 78, poz. 483.

Kowalczyk S., Sobiecki R., Interwencjonizm w erze globalizacji, „Kwartalnik Nauk o Przedsiębiorstwie" 2019, nr 2.

Kundera E. (red.), Słownik historii myśli ekonomicznej, Wolters Kluwer business, Warszawa 2014.

Leszczyński A., Eksperymenty na biednych, Wydawnictwo Krytyki Politycznej, Warszawa 2016.

Leszczyński A., Skok w nowoczesność. Polityka wzrostu w krajach peryferyjnych 1943-1980, Wydawnictwo Krytyki Politycznej, Warszawa 2013.

Malthus T.R, Prawo ludności, Jirafa Roja, Warszawa 2007.

Maslin M., Zmiany klimatu, Wydawnictwo Uniwersytetu Łódzkiego, Łódź 2018.

Mączyńska E., Pysz P., Liberalizm, neoliberalizm i ordoliberalizm, Referat na IX Kongres Ekonomistów Polskich, „Ekonomista”2014, nr 2, http://journals.pan.pl/dlibra/publication/100904/ edition/86921/content [dostęp: 27.02.2020]

Nowicki R., Wywiad z Fukuyama. Liberalizm nie jest przeżytkiem, „Newsweek Polska” 2019, nr 42.

Osiński J., Zawiślińska I. (red.), Polityka publiczna. Teoria. Jakość. Dobre praktyki, Wydawnictwo SGH, Warszawa 2016.

Piątkowski M., Europejski lider wzrostu, Poltext, Warszawa 2019.

Piketty T., Kapital w XXI wieku, Wydawnictwo Krytyki Politycznej, Warszawa 2015.

Richard Musgrave, https://en.wikipedia.org/wiki/Richard Musgrave (economist) [dostęp: 27.02.2020].

Rosati D., Polityka gospodarcza. Wybrane zagadnienia, Wydawnictwo SGH, Warszawa 2017.

Sarkozy N., Słowo wstępne, [w:] J. Stiglitz, A. Sen, J.P. Fitoussi, Bład pomiaru. Dlaczego PKB nie wystarcza, Polskie Towarzystwo Ekonomiczne, Warszawa 2013.

Smith A., Badania nad natura i przyczynami bogactwa narodów, PWN, Warszawa 2007.

Sobecki R., Interwencjonizm, ale jaki?, „Kwartalnik Nauk o Przedsiębiorstwie” 2019, nr 2.

Solska J., Władza za nieróbstwo, „Polityka. Niezbędnik Współczesny” 2019.

Stankiewicz W., Historia myśli ekonomicznej, PWE, Warszawa 2000.

Stiglitz J.E., Ekonomia sektora publicznego, PWN, Warszawa 2004. 
Stiglitz J., Sen A., Fitoussi J.P., Bład pomiaru. Dlaczego PKB nie wystarcza, Polskie Towarzystwo Ekonomiczne, Warszawa 2013.

Wilkin J., Instytucjonalne i kulturowe podstawy gospodarowania, Wydawnictwo Naukowe Scholar, Warszawa 2016.

Żmigrodzki M. (red. nauk.), Encyklopedia politologii, t. 1, Kantor Wydawniczy Zakamycze, Kraków 1999.

\section{Streszczenie}

Polityka gospodarcza jako działanie państwa na tle globalnych zmian

Na tle dynamicznych globalnych zmian społecznych, a także zmian w środowisku biogeograficznym, jedną z ważnych ról państwa jest jego działanie jako regulatora życia gospodarczego. Polityka gospodarcza jest narzędziem państwa w tej dziedzinie. Celem artykułu jest przedstawienie jednego z modeli polityki gospodarczej - polityki społecznej gospodarki rynkowej na tle powstawania nowej rzeczywistości pierwszej połowy XXI wieku.

Słowa kluczowe: zmiany społeczne, działanie państwa, polityka gospodarcza

\section{Summary}

\section{Economic policy as a state action against the backdrop of global changes}

Against the backdrop of dynamic global social changes, as well as changes in the biogeographic environment, one of the important roles of the state is as a regulator of economic life. Economic policy is a state tool in this field. The aim of the article is to present one of the economic policy models - social market economy policy, against the background of creating a new reality for the first half of the $21^{\text {st }}$ century.

Keywords: social changes, state activity, economic policy 